Abstracta Iranica

Revue bibliographique pour le domaine irano-aryen

Volume 34-35-36 | 2017

Comptes rendus des publications de 2011-2013

\title{
Vito Messina. Seleucia on the Tigris. The Babylonian polis of Antiochus I
}

\section{Rémy Boucharlat}

\section{(2) OpenEdition}

10 Journals

\section{Édition électronique}

URL : http://journals.openedition.org/abstractairanica/42279

DOI : 10.4000/abstractairanica.42279

ISSN : 1961-960X

Éditeur :

CNRS (UMR 7528 Mondes iraniens et indiens), Éditions de l'IFRI

Référence électronique

Rémy Boucharlat, «Vito Messina. Seleucia on the Tigris. The Babylonian polis of Antiochus I 》, Abstracta Iranica [En ligne], Volume 34-35-36 | 2017, document 26, mis en ligne le 30 juillet 2017, consulté le 26 septembre 2020. URL : http://journals.openedition.org/abstractairanica/42279 ; DOI : https://doi.org/ $10.4000 /$ abstractairanica.42279

Ce document a été généré automatiquement le 26 septembre 2020.

Tous droits réservés 


\title{
Vito Messina. Seleucia on the Tigris. The Babylonian polis of Antiochus I
}

\author{
Rémy Boucharlat
}

\section{RÉFÉRENCE}

Vito Messina. « Seleucia on the Tigris. The Babylonian polis of Antiochus I ». Mesopotamia, 46, 2011, p. 157-167.

1 Résumé des principales caractéristiques de la capitale séleucide. Les fouilles américaines (1927-36) et italiennes (1964-1989) n'ont touché que 5\% des 550 ha du site. Dans l'urbanisme hippodamien (grille de blocs 140x70m, soit 500x250 pieds attiques), le plan interne a été précisément reconnu pour l'un des blocs. L'architecture et la fonction des bâtiments témoignent des deux traditions : grecque, comme le théâtre ou la stoa, et orientale, comme un petit temple de plan mésopotamien accolé au théâtre. La conception de la ville est à l'image du fondateur, Antiochos I, fils du Grec Séleucos et d'une princesse iranienne, dont on sait qu'il célébrait certaines fêtes locales et s'intitulait protecteur des temples locaux.

\section{AUTEURS}

RÉMY BOUCHARLAT

UMR 5133 CNRS-Université de Lyon 